\title{
The Effects of Utilitarian and Hedonic Values on Young Consumers' Satisfaction and Behavioral Intentions
}

\author{
Umit BASARAN*, Ozan BUYUKYILMAZ**
}

\begin{abstract}
This study aims to investigate the effects of utilitarian and hedonic values on young consumers' satisfaction and behavioral intentions in fast-food and fast-casual restaurant sectors comparatively. Also this study investigates which value component (utilitarian or hedonic) is more effective on satisfaction and behavioral intentions. The results show that utilitarian and hedonic values have significant effects on satisfaction and behavioral intentions for both fast-food and fast-casual restaurant sectors. Additionally, satisfaction has an influence on behavioral intentions in fast-food restaurant sector, but does not have a significant effect in fast-casual restaurant sector. Moreover, associations between hedonic value with satisfaction and behavioral intentions are significantly different between fast-food and fast-casual restaurant sectors. On the other hand, associations between utilitarian value with satisfaction and behavioral intentions and association between satisfactions with behavioral intentions are not significantly different between fast-food and fast-casual restaurant sectors.
\end{abstract}

Keywords: Utilitarian Value, Hedonic Value, Satisfaction, Behavioral Intentions, Young Consumers.

JEL Code Classification: M31, M39, L66, L83

UDC: [640.433: 17.036.11-053.81]: 303.725.33

\footnotetext{
* Corresponding Author, Assistant Professor, Department of Business Administration, Bulent Ecevit University, Zonguldak, Turkey, E-Mail: umbasaran@gmail.com

** Assistant Professor, Department of Business, Karabuk University, Karabuk, Turkey, E-Mail: ozanbuyukyilmaz@karabuk.edu.tr
} 


\section{Introduction}

The researchers suggest that there exists two kinds of consumer evaluation, in which a consumption object is cognitively placed on both a utilitarian dimension of instrumentality (e.g., how useful or beneficial the object is), and on a hedonic dimension measuring the experiential effect associated with the object (e.g., how pleasant and agreeable those associated feelings are) (Batra \& Ahtola, 1990:161). Hence, only utilitarian or just hedonic factors are thought to be insufficient to explain consumer behaviors. Utilitarian consumption means a product or service is purchased in a task-related, rational and efficient manner (Babin et al., 1994:646). On the contrary, hedonic consumption means purchasing is primarily motivated by the desire for sensual pleasure, fantasy, and fun (Ryu et al., 2010:417).

In restaurant sector, the factors that consumers give importance might vary in terms of consumption experiences (Babin et al., 2005; Ryu et al., 2010; Hanzaee \& Khonsari, 2011; Nejati \& Moghaddam, 2012; Nejati \& Moghaddam, 2013). The consumptions like just feeding, not losing a lot of time or eating healthily are considered as goal-oriented or utilitarian consumptions. In contrast, the consumptions like taking pleasure from the restaurant environment, getting social, enjoying oneself or tasting new flavors are stated as pleasure-oriented or hedonic consumptions.

A fast-food restaurant is a type of restaurant which offers foods prepared in a short time, immediately consumed or packaged. Also, these restaurants are characterized by both their limited menu content and minimal table service (e.g., Burger King, McDonald's, Popeyes, KFC, etc.) (Park, 2004: 87-88). A fast-casual restaurant is a type of restaurant that promises consumers a higher quality of foods, table service and atmosphere compared to fast-food restaurants. Besides, these restaurants have higher menu prices than fast-food restaurants (e.g., Hard Rock Cafe, Nando's, Chipotle, etc.) (Tillotson, 2003:91; Ryu et al., 2010:417; Nejati \& Moghaddam, 2012:337).

In recent years, due to the rapid changes in consumer preferences and desires, fast-casual restaurants are becoming new and growing concepts in addition to fastfood restaurants (Ryu and Han, 2010:310). Therefore, in the restaurant sector, in terms of young consumers who are eat out intensively, it is important to determine the effectiveness of usefulness and playfulness separately.

Determining the values that affect consumers' satisfaction and behavioral intentions is an important subject in the consumer behavior and services marketing literature. In the literature, there are studies which investigate the effects of utilitarian and hedonic values on patronage, satisfaction and behavioral intentions (Babin et al., 2005; Jones et al., 2006; Carpenter, 2008; Ryu et al., 2010; Hanzae \& Khonsari, 2011; Nejati \& Moghaddam, 2013; Chiu et al., 2014; Josiam \& Henry, 2014), but a study that investigates these effects mutually between fast-food and fast-casual restaurant sectors has not been observed. Accordingly, the aim of this 
study is to investigate the effects of utilitarian and hedonic values on young consumers' satisfaction and behavioral intentions in fast-food and fast-casual restaurant sectors. Also it is investigated which value component (utilitarian or hedonic) is more effective on satisfaction and behavioral intentions in these sectors.

In the study two fast-food and two fast-casual restaurants were considered which are located in a shopping mall in Zonguldak, Turkey. In Zonguldak, there is one shopping mall and most of the fast-food and fast-casual restaurants are located in it. Also, there is one state university and the shopping mall is located very close to the university. Therefore, young consumers (university students) frequently visit the shopping mall to eat out from fast-food and fast-casual restaurants. There are two global (Burger King, Popeyes) and two local (Ortakoy Kumpir, Pideium) fastfood restaurants. Also there is one global (Sbarro) and three local (Citir Usta, Freshium Salads, Pizza House) fast-casual restaurants.

This study is expected to contribute to the literature by analyzing the effects of utilitarian and hedonic values in fast-food and fast-casual restaurant sectors comparatively. Moreover, it is anticipated to be important in terms of practice by leading the way to fast-food and fast-casual restaurateurs that want to provide better service value to their consumers and in turn improve satisfaction and positive behavioral intentions of consumers.

\section{Literature Review}

\subsection{Utilitarian and Hedonic Values}

Consumption activities have utilitarian and hedonic aspects (Babin et al., 1994). For example, some consumers are only interested in the functional dimensions of shopping and see the consumption activity as a task. On the other hand, some consumers want to have fun when they do shopping. So these consumers deal with the hedonic, symbolic or emotional dimensions of shopping and they see the consumption activity as fun. Therefore, shopping values need to be evaluated separately in terms of utilitarian and hedonic values.

Utilitarian consumption derives from 'the functions performed by the product or service' (Voss et al., 2003:310). Utilitarian buying motives include desires like convenience-seeking, variety seeking, searching for quality of product or service, and reasonable price rate (Sarkar, 2011:58). Accordingly, utilitarian motivation shows that shopping starts from a mission or task, and the acquired benefit depends on whether the mission is completed or not or whether the mission is completed efficiently during the shopping process (To et al., 2007:775).

Hedonic consumption relates to the multi- sensory, fantasy and emotive aspects of one's experience with products or services (Hirschman \& Holbrook, 1982:92). Consumers perceived hedonic value more subjective and personal than utilitarian 
value and usually it is obtained by entertainments, playfulness but not by implementation of tasks (Kazakeviciute \& Banyte, 2012:534). Hedonic value reflects the individual's evaluation of the entertainment and experiential worth of the shopping trip (e.g., fun, experiential part of shopping) (Eroglu et al., 2005:1147).

\subsection{Satisfaction}

Oliver (1980) demonstrates that satisfaction is a function of expectation and expectancy disconfirmation in a cognitive model of the antecedents and consequences of satisfaction decisions (Oliver, 1980:460).

The model asserts that attitudes towards a product or service are shaped by the performance specific expectations of consumer. After consuming the product or service, consumers evaluate the experience of purchasing or the performance of the product or service relative to their pre-purchase expectations. If the evaluations confirm the consumers' pre-purchase expectations, consumer satisfaction occurs. This satisfaction creates a positive attitude and may positively influence the repurchase intentions. On the other hand, if the evaluations disconfirm the pre-purchase expectations, consumer dissatisfaction occurs. In this case, dissatisfaction leads a negative attitude towards the purchasing experience and product or service and it may be a negative effect on future purchase intentions (Oliver, 1980:460-469). Therefore, satisfaction is an outcome of purchase and use resulting from the consumer's comparison of the rewards and costs of the purchase in relation to the anticipated consequences (Churchill \& Surprenant, 1982:493).

\subsection{Behavioral Intentions}

Consumers develop an attitude towards previous purchasing experience depending on a state of satisfaction or dissatisfaction (Oliver, 1980:460-469). The attitude takes the form of liking or disliking, and is based on many separate evaluations of product or service features that are combined using various heuristics (Oliver, 2010:22). This attitude may strongly influence the future behavioral intentions of consumer. Behavioral intentions are defined as a stated likelihood to engage in a certain behavior (Oliver, 2010:23). Consumers develop behavioral intentions like repurchasing, spreading by word of mouth, paying more, switching and complaining (Zeithaml et al., 1996:38).

In this study, behavioral intentions are discussed as visiting the restaurant again (repurchase intention) and recommending the restaurant to family, friends or others (word of mouth) in the future. Repurchase intention, which means an intention to repurchase product or service a consumer has bought, is defined as an intention to repeatedly use product or service in the future and, based on previous experiences and expectations for the future (Kim et al., 2011:37). In addition, consumer word of mouth transmissions consist of informal communications 
directed at other consumers about the ownership, usage, or characteristics of particular product or service and their seller (Westbrook, 1987:261).

\section{Hypotheses Development}

Researchers suggest that satisfaction should be viewed as a response to an evaluation process that occurs in post-purchase (Oliver, 1981:27; Churchill \& Surprenant, 1982:493; Fornell, 1992:11; Garbarino \& Johnson, 1999:71; Carpenter, 2008:359). Therefore, satisfaction could be formed as the result of the consumer's evaluation of the value derived from the shopping experience (Carpenter, 2008:359). Several researches show that hedonic value and utilitarian value have an effect on satisfaction (Babin et al., 1994:651; Babin et al., 2005:137; Cottet et al., 2006:222; Jones et al., 2006:978; Carpenter, 2008:361; Irani \& Hanzaee, 2011:95; Chang \& Fang, 2012:2256).

In this context, Babin et al. (2005), in their research which was applied on consumers at family-style chain dinner houses in a large metropolitan area in South Korea, found that hedonic value and utilitarian value are related positively to satisfaction. Ryu et al. (2010) applied a research in the fast-casual restaurant sector in USA and findings display similar results with positive estimates for the relationships between hedonic value, utilitarian value and satisfaction. Similar results were determined in a research which was carried out in the fast-casual restaurant sector in Iran (Hanzee \& Khonsari, 2011). Thus, H1 and H2 hypotheses are offered as follows.

H1: Hedonic value has a positive and significant effect on satisfaction.

H1a: Hedonic value has a positive and significant effect on satisfaction in the fastfood restaurant sector.

H1b: Hedonic value has a positive and significant effect on satisfaction in the fastcasual restaurant sector.

H2: Utilitarian value has a positive and significant effect on satisfaction.

H2a: Utilitarian value has a positive and significant effect on satisfaction in the fastfood restaurant sector.

H2b: Utilitarian value has a positive and significant effect on satisfaction in the fastcasual restaurant sector.

Researches show that hedonic value and utilitarian value among consumers influence positive behavioral intentions like purchasing again in the future and saying positive things to others (Jones et al., 2006; Ryu et al., 2010; Hanzaee \& Khonsari, 2011; Chang \& Fang, 2012; Nejati \& Moghaddam, 2012). Hanzaee and Khonsari (2011) supported a direct relationship between hedonic value, utilitarian value and repurchase intention. Chang and Fang (2012) conducted a research on department store and hypermarket samples in Taiwan and findings show that hedonic and utilitarian values have significant influences on word of mouth and repatronage intentions. Jones et al. (2006) found that hedonic value has an 
influence on positive word of mouth and loyalty, in return utilitarian value has an influence on loyalty and repatronage intentions. Therefore, $\mathrm{H} 3$ and $\mathrm{H} 4$ hypotheses are offered as follows.

H3: Hedonic value has a positive and significant effect on behavioral intentions.

H3a: Hedonic value has a positive and significant effect on behavioral intentions in the fast-food restaurant sector.

$H 3 b$ : Hedonic value has a positive and significant effect on behavioral intentions in the fast-casual restaurant sector.

H4: Utilitarian value has a positive and significant effect on behavioral intentions.

H4a: Utilitarian value has a positive and significant effect on behavioral intentions in the fast-food restaurant sector.

$H 4 b$ : Utilitarian value has a positive and significant effect on behavioral intentions in the fast-casual restaurant sector.

Several researches have provided empirical evidence for a positive relationship between satisfaction and behavioral intentions, such as repurchase and word of mouth (Babin et al., 2005; Carpenter, 2008; Ryu et al., 2008; Ha and Jang, 2010; Ryu et al., 2010; Terblanche \& Boshoff, 2010). In their research that was conducted with actual customers at quick-casual restaurants, Ryu et al. (2008) found a significant effect of satisfaction on behavioral intentions. Terblanche and Boshoff (2010) determined that satisfaction appears to be a good predictor of customer loyalty in the South African fast-food industry. Babin et al. (2005) similarly reported that increased satisfaction is associated with increased word of mouth. Ha and Jang (2010) suggested that satisfaction is a significant antecedent of behavioral intentions in their research that was conducted at Korean restaurants. Hence, H5 hypothesis is offered as follows.

H5: Satisfaction has a positive and significant effect on behavioral intentions.

H5a: Satisfaction has a positive and significant effect on behavioral intentions in the fast-food restaurant sector.

H5b: Satisfaction has a positive and significant effect on behavioral intentions in the fast-casual restaurant sector.

Researchers determined different findings about the effects of hedonic and utilitarian values on satisfaction and behavioral intentions in the restaurant sector (Babin et al., 2005; Ryu et al., 2010; Hanzaee \& Khonsari, 2011; Nejati \& Moghaddam, 2012; Nejati \& Moghaddam, 2013). In a sample of Korean restaurant consumers, Babin et al. (2005) found that hedonic value has a greater effect on satisfaction than utilitarian value. Conversely, utilitarian value was found to have a greater effect on word of mouth intentions than hedonic value has (Babin et al., 2005:137). In fast-casual restaurant sector in Iran, Hanzaee and Khonsari (2011) reported that utilitarian value was more effective on both satisfaction and repurchase intention than hedonic value. Similar results are also supported by Ryu et al. (2010) in their research for fast-casual restaurant sector in USA. On the other 
hand, a different research revealed that hedonic value plays more important role on behavioral intentions than utilitarian value, in the context of fast-casual restaurants in Iran (Nejati \& Moghaddam, 2012:340). It is also indicated that utilitarian value has a more powerful influence on satisfaction of customers in the context of fast-food restaurants in Iran (Nejati \& Moghaddam, 2013:1590).

In this research, the effects of hedonic and utilitarian values on satisfaction and behavioral intentions are analyzed in the context of fast-food and fast-casual restaurant sectors simultaneously. There are various motivations for eating out between consumers. These can be utilitarian factors like economizing and efficiency or hedonic factors such as fun, taste, and social interaction (Park, 2004:88). Therefore, in the context of fast-food restaurants which service foods in a short time with its limited menu content, it is expected that utilitarian value will have greater effect on young consumers' satisfaction and behavioral intentions. Conversely, in the context of fast-casual restaurants which offer consumers a higher quality of foods, table service and atmosphere compared to fast-food restaurants, it is expected that hedonic value will have greater effect on young consumers' satisfaction and behavioral intentions. Thus, H6, H7, H8 and H9 hypotheses are offered as follows.

H6: The effect of hedonic value on satisfaction is significantly different between the fast-food and fast-casual restaurant sectors.

H7: The effect of utilitarian value on satisfaction is significantly different between the fast-food and fast-casual restaurant sectors.

H8: The effect of hedonic value on behavioral intentions is significantly different between the fast-food and fast-casual restaurant sectors.

H9: The effect of utilitarian value on behavioral intentions is significantly different between the fast-food and fast-casual restaurant sectors.

The effect of satisfaction on behavioral intentions is also wanted to be investigated whether there exists difference between fast-food and fast-casual restaurant sectors. Therefore, $\mathrm{H} 10$ hypothesis is offered as follows.

H10: The effect of satisfaction on behavioral intentions is significantly different between the fast-food and fast-casual restaurant sectors.

\section{Research Methodology}

\subsection{Measures}

In the study the scales were created by using prior studies in the literature. The scale items used in the questionnaire were created using the 5 point Likert type scale (1=strongly disagree, $2=$ disagree, $3=$ =neutral, 4=agree, 5=strongly agree).

The hedonic and utilitarian value scales were adapted from the scales which were used by Babin et al. (1994) and Ryu et al. (2010). The hedonic value scale consists of six items and the utilitarian value scale consists of five items. The satisfaction scale 
was adapted from the scales which were used by Oliver et al. (1997) and McDougall and Levesque (2000). The scale consists of two items. The behavioral intentions scale was adapted from the scale which was used by Zeithaml et al. (1996). The scale consists of four items. The reliability estimates (Cronbach's alpha) of measures both for fast-food and fast-casual samples are reported in findings section.

\subsection{Sample and Data Collection}

The population of the study consists of all students who are educated at Faculty of Economics and Administrative Sciences in Bulent Ecevit University in Zonguldak, Turkey. Young consumers may have more tendencies to eat out in fast-food and fast-casual restaurants than other consumers. Hence, this reason has been effective in the selection of the population. According to information received from student affairs, there are 3575 students at the faculty. The minimum sample size was calculated as 351 people (Sekaran, 2003:294). The questionnaire was performed on 575 students who selected by convenience sampling method. As a result of the examination, 51 questionnaires were regarded as invalid. In addition, it has been determined that 93 questionnaires were filled by only fast-food or only fast-casual consumers. Hence, 144 questionnaires were ejected from the study. Consequently, 431 questionnaires were evaluated in the study. The descriptive statistics of the respondents being analyzed are summarized in Table 1.

The survey method was used to collect data in the study. The questionnaire consists of three parts. In the first part, there are questions which measure the demographic characteristics of the respondents. In the second and third parts, there are statements which measure the perceived hedonic and utilitarian value, satisfaction and behavioral intentions of respondents for fast-food and fast-casual restaurant sectors. In the study two fast-food and two fast-casual restaurants were considered which are located in a shopping mall in Zonguldak, Turkey. Respondents, when filling out the questionnaire, were asked to evaluate the latest fast-food and fast-casual restaurants where they got service. Answers were collected between January 7 and February 5, 2013.

\subsection{Data Analysis}

Data were analyzed using the two-step procedure suggested by Anderson and Gerbing (1988). First, a confirmatory factor analysis (CFA) was performed to examine the construct validity of the studied constructs (hedonic and utilitarian value, satisfaction, behavioral intentions). Second, a structural equation modeling (SEM) with latent variables via AMOS was tested to determine the adequacy of the constructs of the model and test the hypotheses. The hedonic value and utilitarian value were predictor variables and satisfaction and behavioral intentions were criterion variables in the analysis. 
The Effects of Utilitarian and Hedonic Values on Young Consumers' Satisfaction...

\section{Findings}

\subsection{Measurement Model}

A confirmatory factor analysis (CFA) using AMOS software was performed both for fast-food, fast-casual and total sample to examine the construct validity of the studied constructs (hedonic value, utilitarian value, satisfaction and behavioral intentions). Overall model fit was tested using fit indices including the root mean square error of approximation (RMSEA), goodness of fit index (GFI), adjusted goodness of fit index (AGFI), normed fit index (NFI), Tucker-Lewis index (TLI), and comparative fit index (CFI). To ensure that the four-factor model was the most appropriate representation of the data, the fit of a three-factor, two-factor and one-factor model was examined across the fast-food sample, fast-casual sample, and the total sample. As seen in Table 1, the four-factor model was the best-fitting model within each sample.

Table 1. Comparison of Measurement Models

\begin{tabular}{lcccccccccc}
\hline & $\chi 2(\mathrm{df})$ & $\Delta \chi 2(\Delta \mathrm{df})$ & $\chi 2 / \mathrm{df}$ & RMSEA & GFI & AGFI & NFI & TLI & CFI \\
\hline Fast-Food ( $\mathrm{n}=431)$ & & & & & & & & & \\
\hline Four-factor model & $259.38(110)$ & - & 2.36 & 0.06 & 0.93 & 0.91 & 0.94 & 0.96 & 0.96 \\
Three-factor model & $600.67(113)$ & $341.29(3)$ & 5.32 & 0.10 & 0.87 & 0.83 & 0.86 & 0.86 & 0.88 \\
Two-factor model & $1092.24(115)$ & $832.86(5)$ & 9.50 & 0.14 & 0.72 & 0.63 & 0.74 & 0.72 & 0.76 \\
One-factor model & $1358.60(116)$ & $1099.22(6)$ & 11.71 & 0.16 & 0.69 & 0.59 & 0.68 & 0.65 & 0.70 \\
\hline Fast-Casual (n=431) & & & & & & & & & \\
\hline Four-factor model & $226.11(110)$ & - & 2.06 & 0.05 & 0.95 & 0.92 & 0.94 & 0.96 & 0.97 \\
Three-factor model & $572.90(113)$ & $346.79(3)$ & 5.07 & 0.10 & 0.87 & 0.83 & 0.84 & 0.84 & 0.87 \\
Two-factor model & $768.22(115)$ & $542.11(5)$ & 6.68 & 0.12 & 0.82 & 0.76 & 0.79 & 0.78 & 0.81 \\
One-factor model & $950.56(116)$ & $724.45(6)$ & 8.19 & 0.13 & 0.77 & 0.70 & 0.74 & 0.72 & 0.76 \\
\hline Total (fast-food and fast-casual combined) (n=862) & & & & & & & \\
\hline Four-factor model & $305.99(110)$ & - & 2.78 & 0.05 & 0.96 & 0.94 & 0.96 & 0.97 & 0.98 \\
Three-factor model & $988.43(113)$ & $682.44(3)$ & 8.75 & 0.10 & 0.89 & 0.85 & 0.88 & 0.87 & 0.89 \\
Two-factor model & $2316.26(115)$ & $2010.27(5)$ & 20.14 & 0.15 & 0.70 & 0.60 & 0.72 & 0.68 & 0.73 \\
One-factor model & $2844.21(116)$ & $2538.22(6)$ & 24.52 & 0.17 & 0.65 & 0.53 & 0.65 & 0.60 & 0.66 \\
\hline
\end{tabular}

Note: RMSEA=root mean square error of approximation, GFI=goodness of fit index, AGFI=adjusted goodness of fit index, NFI=normed fit index, TLI=Tucker-Lewis index, $\mathrm{CFI}=$ comparative fit index

\subsection{Descriptive Statistics}

The means, standard deviations, zero-order correlations, and reliability estimates (Cronbach's alpha) for the measures used in the study are reported both for fastfood and fast-casual samples in Table 2. As seen in the table, zero-order correlations all were in the expected direction and the internal consistency ( $\alpha$ ) for each measure was above .70 as recommended by Nunnally and Bernstein (1994). 
In addition, correlations between measures never exceeded 0.85 , suggesting that no bivariate multicollinearity exists between scales (Kline, 2011).

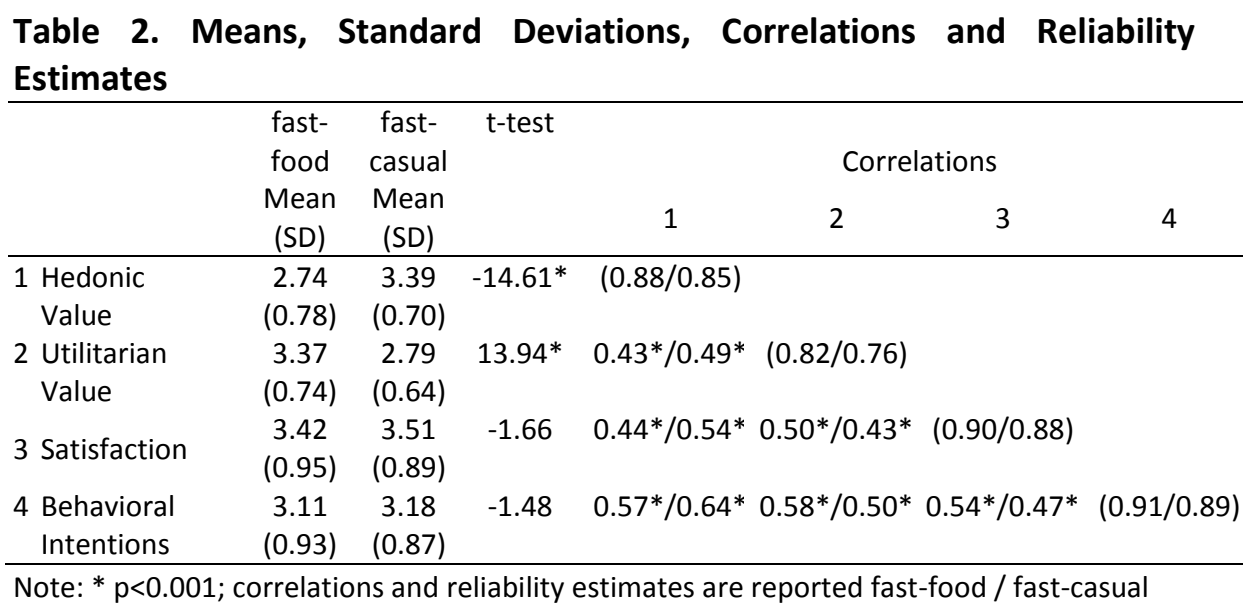

An independent t-test was conducted to determine if there was any significant difference in terms of perception of hedonic value, utilitarian value, satisfaction and behavioral intentions between fast-food sample and the fast-casual sample. Ttest did not yield any significant difference between the mean scores of the fastfood sample and the fast-casual sample in respect of satisfaction $(t=-1.66, p>0.05)$ and behavioral intentions ( $t=-1.48, p>0.05)$. On the other hand, $t$-test showed that there was a significant difference between the mean scores of fast-food sample and the fast-casual sample in respect of hedonic value $(t=-14.61, p<0.01)$ and utilitarian value $(t=13.94, p<0.01)$. These results suggest that the perception of hedonic value is higher in fast-casual restaurants $(M=3.39 ; S D=0.70)$ than fast-food restaurants $(M=2.74 ; S D=0.78)$ and the perception of utilitarian value is higher in fast-food restaurants $(M=3.37 ; S D=0.74)$ than fast-casual restaurants $(M=2.79$; $S D=0.64)$. This calls for a closer examination of the interrelationship between the different variables.

\subsection{Hypotheses Testing and Path Analysis}

Structural Equation Modeling (SEM) with multi-group analysis was used in order to test the hypothesized relations in the research model. Overall model fit results and squared multiple correlations are shown in Table 3. The results indicated a good fit of the model $(\chi 2 / \mathrm{df}=2.21, \mathrm{RMSEA}=0.04, \mathrm{GFI}=0.94, \mathrm{AGFI}=0.91, \mathrm{NFI}=0.94, \mathrm{TLI}=0.96$, $\mathrm{CFI}=0.97)$. Moreover, for fast-food restaurant sector, the model explained approximately $38 \%$ (SMC $=0.38$ ) of the variance in satisfaction and $59 \%$ in behavioral intentions. The model for fast-casual restaurant sector explained approximately $41 \%$ of the variance in satisfaction and explained $57 \%$ of the variance in behavioral intentions. Therefore, it can be concluded that the models 
can successfully predict participants' satisfaction and behavioral intentions for both fast-food and fast-casual restaurant sectors.

Table 3. Fit Statistics and Squared Multiple Correlations

\begin{tabular}{cccccccc}
\hline \multicolumn{10}{l}{ Model Fit Indices } \\
\hline$\chi 2$ (df) & $\chi 2 / \mathrm{df}$ & RMSEA & GFI & AGFI & NFI & TLI & CFI \\
$485.49(220)$ & 2.21 & 0.04 & 0.94 & 0.91 & 0.94 & 0.96 & 0.97 \\
\hline \multicolumn{7}{l}{ Squared Multiple Correlations (SMC) } \\
\hline \multicolumn{7}{c}{ Fast-Food } & Fast-Casual \\
Satisfaction & 0.38 & 0.41 & \\
Behavioral Intentions & 0.59 & 0.57 & \\
\hline
\end{tabular}

All results are shown in Table 4 and the SEM path diagrams are shown in Figure 1.

\section{Table 4. Testing the Hypothesis}

\begin{tabular}{|c|c|c|c|c|c|c|c|}
\hline \multicolumn{5}{|c|}{ Hypotheses } & SC & CR & $\begin{array}{c}\text { Hypotheses } \\
\text { Testing }\end{array}$ \\
\hline $\mathrm{H} 1 \mathrm{a}$ & \multicolumn{4}{|c|}{ a Hedonic Value --> Satisfaction (Fast-Food) } & $0.23 *$ & 4.09 & Supported \\
\hline $\mathrm{H} 1 \mathrm{~b}$ & \multicolumn{4}{|c|}{ Hedonic Value --> Satisfaction (Fast-Casual) } & $0.45^{*}$ & 6.14 & Supported \\
\hline $\mathrm{H} 2 \mathrm{a}$ & \multicolumn{4}{|c|}{ Utilitarian Value --> Satisfaction (Fast-Food) } & $0.48 *$ & 7.32 & Supported \\
\hline $\mathrm{H} 2 \mathrm{~b}$ & \multicolumn{4}{|c|}{ Utilitarian Value --> Satisfaction (Fast-Casual) } & $0.25 *$ & 3.46 & Supported \\
\hline H3a & \multicolumn{4}{|c|}{ Hedonic Value --> Behavioral Intentions (Fast-Food) } & $0.31 *$ & 6.25 & Supported \\
\hline $\mathrm{H} 3 \mathrm{~b}$ & \multicolumn{4}{|c|}{ Hedonic Value --> Behavioral Intentions (Fast-Casual) } & $0.53 *$ & 7.01 & Supported \\
\hline $\mathrm{H} 4 \mathrm{a}$ & \multicolumn{4}{|c|}{ Utilitarian Value --> Behavioral Intentions (Fast-Food) } & $0.40 *$ & 6.35 & Supported \\
\hline $\mathrm{H} 4 \mathrm{~b}$ & \multicolumn{4}{|c|}{ Utilitarian Value --> Behavioral Intentions (Fast-Casual) } & $0.23 *$ & 3.52 & Supported \\
\hline $\mathrm{H} 5 \mathrm{a}$ & \multicolumn{4}{|c|}{ Satisfaction --> Behavioral Intentions (Fast-Food) } & $0.22 *$ & 4.17 & Supported \\
\hline \multirow[t]{3}{*}{$\mathrm{H} 5 \mathrm{~b}$} & \multicolumn{4}{|c|}{ Satisfaction --> Behavioral Intentions (Fast-Casual) } & 0.08 & 1.41 & Not Supported \\
\hline & & & & & & \multicolumn{2}{|c|}{ Difference } \\
\hline & & $B_{\text {fast-food }}$ & $S E_{\text {fast-food }}$ & $\mathrm{B}_{\text {fast-casual }}$ & $S E_{\text {fast-casual }}$ & z-value & $\begin{array}{c}\text { Hypotheses } \\
\text { Testing } \\
\end{array}$ \\
\hline H6 & $\begin{array}{l}\text { Hedonic Value --> } \\
\text { Satisfaction }\end{array}$ & 0.30 & 0.073 & 0.70 & 0.114 & $2.94 * *$ & Supported \\
\hline H7 & $\begin{array}{l}\text { Utilitarian Value --> } \\
\text { Satisfaction }\end{array}$ & 0.71 & 0.096 & 0.42 & 0.121 & -1.87 & Not Supported \\
\hline $\mathrm{H} 8$ & $\begin{array}{l}\text { Hedonic Value --> } \\
\text { Behavioral Intentions }\end{array}$ & 0.39 & 0.062 & 0.74 & 0.107 & $2.88^{* *}$ & Supported \\
\hline H9 & $\begin{array}{l}\text { Utilitarian Value --> } \\
\text { Behavioral Intentions }\end{array}$ & 0.55 & 0.087 & 0.36 & 0.101 & -1.43 & Not Supported \\
\hline $\mathrm{H} 10$ & $\begin{array}{l}\text { Satisfaction --> } \\
\text { Behavioral Intentions }\end{array}$ & 0.21 & 0.049 & 0.07 & 0.051 & -1.86 & Not Supported \\
\hline
\end{tabular}

Note: $* \mathrm{p}<0.001, * * \mathrm{p}<0.01 ; \mathrm{SC}=$ standardized coefficient, $\mathrm{CR}=$ critical ratio, $\mathrm{B}=$ unstandardized coefficients, $\mathrm{SE}=$ standard error 


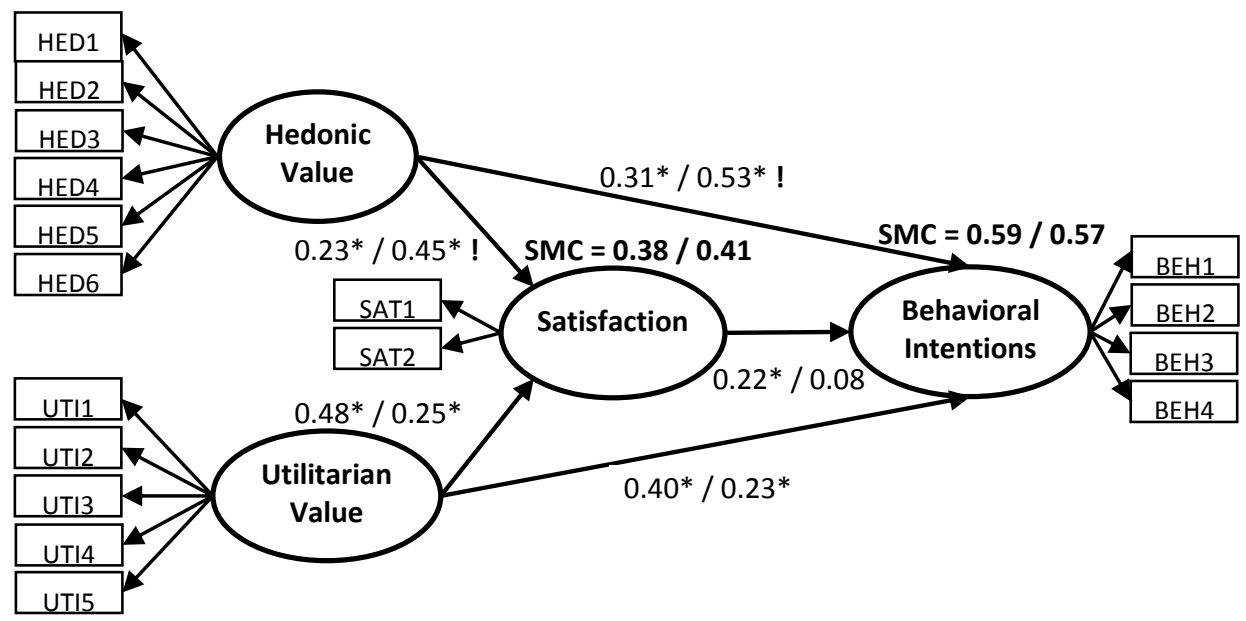

Note: ${ }^{*} p<0.001$; paths and squared multiple correlations (SMC) are reported fast-food / fast-casual; ! significantly different paths

\section{Figure 1. Path Diagram for Fast-Food and Fast-Casual Restaurant Sectors}

Hypotheses $\mathrm{H} 1$ and $\mathrm{H} 2$ predicted that hedonic value and utilitarian value would be related to satisfaction for both fast-food and fast-casual restaurant sectors. As shown in Table 4, hedonic value was significantly and positively associated with satisfaction for fast-food restaurant sector ( $\mathrm{H} 1 \mathrm{a}: \beta=0.23, \mathrm{p}<0.001)$ and fast-casual restaurant sector $(\mathrm{H} 1 \mathrm{~b}: \beta=0.45, \mathrm{p}<0.001)$, and utilitarian value was significantly and positively associated with satisfaction for fast-food restaurant sector $(\mathrm{H} 2 \mathrm{a}$ : $\beta=$ $0.48, p<0.001)$ and fast-casual restaurant sector ( $\mathrm{H} 2 \mathrm{~b}: \beta=0.25, \mathrm{p}<0.001)$. Thus, hypotheses 1 and 2 were all supported.

The precursors of behavioral intentions were examined with hypotheses $\mathrm{H} 3, \mathrm{H} 4$ and H5. As shown in Table 4, hedonic value was significantly and positively associated with behavioral intentions for fast-food restaurant sector ( $\mathrm{H} 3 \mathrm{a}$ : $\beta=0.31$, $p<0.001$ ) and fast-casual restaurant sector (H3b: $\beta=0.53, p<0.001$ ). Similarly, utilitarian value was significantly and positively associated with behavioral intentions for fast-food restaurant sector ( $\mathrm{H} 4 \mathrm{a}: \beta=0.40, p<0.001)$ and fast-casual restaurant sector $(\mathrm{H} 4 \mathrm{~b}: \beta=0.23, \mathrm{p}<0.001)$. Satisfaction was significantly and positively associated with behavioral intentions for fast-food restaurant sector ( $\mathrm{H} 5 \mathrm{a}: \beta=0.22, p<0.001$ ), but was not significantly associated with behavioral intentions for fast-casual restaurant sector (H5b: $\beta=0.08, p>0.05$ ). Therefore, hypotheses 3 and 4 gained support, but hypothesis 5 was partially supported.

To examine the differences in standardized coefficients for the model between fast-food and fast-casual restaurant sectors ( $\mathrm{H} 6-\mathrm{H} 10)$, critical ratios comparison was used. For testing the equivalence of model parameters across fast-food and fast-casual restaurant sectors, pairwise parameter comparisons which is available 
in AMOS's "Critical Ratio for Differences between Parameters" command was utilized. Pairwise parameter comparisons test whether two parameters are significantly different from one another by calculating the difference between the two estimates divided by the estimated standard error of the difference. The resulting difference statistic is tested against the z-score distribution. The precise value of $z$ for the 0.05 level is 1.96 and for the 0.01 level it is 2.58 (Byrne, 2010:136; Kline, 2011:34).

Comparisons of model parameters revealed that association between hedonic value and satisfaction ( $\mathrm{H6}$ : $\mathrm{F}=2.94, \mathrm{p}<0.01)$, and association between hedonic value and behavioral intentions ( $\mathrm{H} 8: \mathrm{F}=2.88, \mathrm{p}<0.01$ ) were significantly different between fast-food and fast-casual restaurant sectors. Therefore, hypotheses 6 and 8 were supported. However, the results indicated that association between utilitarian value and satisfaction ( $\mathrm{H7}$ : $\mathrm{F}=-1.87, \mathrm{p}>0.05)$, association between utilitarian value and behavioral intentions ( $\mathrm{H} 9$ : $\mathrm{F}=-1.43, \mathrm{p}>0.05)$, and association between satisfaction and behavioral intentions ( $\mathrm{H} 10: \mathrm{F}=-1.86, \mathrm{p}>0.05)$ were not significantly different between fast-food and fast-casual restaurant sectors. Therefore, hypotheses 7, 9 and 10 were not supported.

\section{Conclusion and Recommendations}

The purpose of this study is to investigate the effects of utilitarian and hedonic values on young consumers' satisfaction and behavioral intentions in fast-food and fast-casual restaurant sectors. Also it is investigated that which value component (utilitarian or hedonic) is more effective on satisfaction and behavioral intentions in these sectors. Therefore, the proposed model was tested on 431 students with SEM analysis.

The study results provide both theoretical and practical implications. Theoretically, this study investigates the relationships between customer value, satisfaction and behavioral intentions in service sector. Customer value was separated into two distinct constructs as hedonic value and utilitarian value based on Babin et al.'s (1994) measure of shopping value. Thus, the usefulness of these two types of shopping value was confirmed for the service sectors similarly Babin et al. (2005), Ryu et al. (2010), Hanzaee and Khonsari (2011). Also, this study contributes to literature by comparatively examining the relationships of constructs in two different restaurant sectors as fast-food and fast-casual.

Practically, similar to previous studies (Babin et al., 2005; Cottet et al., 2006; Jones et al., 2006; Carpenter, 2008; Ryu et al., 2010; Chang \& Fang, 2012) the findings indicate that both hedonic and utilitarian values have significant effects on satisfaction and behavioral intentions for both fast-food and fast-casual restaurant sectors. Additionally, satisfaction has an influence on customers' behavioral intentions for fast-food restaurant sector. Therefore, the businesses that operate in the fast-food and fast-casual restaurant sectors are expected to develop strategies 
for enhancing hedonic and utilitarian values in order to ensure satisfaction and positive behavioral intentions. In this way, if fast-food and fast-casual restaurateurs provide more value for their customers, they will meet the satisfaction and improve the probability of customers' revisiting the restaurant and talking others positively about the restaurant and eating experiences.

In practical implications, the effect of hedonic value on satisfaction and behavioral intentions is greater for fast-casual restaurant sector than fast-food restaurant sector. In addition, this difference is statistically significant. This finding shows that while the utilitarian value is an important predictor of satisfaction and behavioral intentions, hedonic aspects of customer value play a greater role in satisfaction and behavioral intentions in the fast-casual restaurant sector. This means hedonic aspects of customer value are more important than utilitarian aspects for satisfaction and behavioral intentions in fast-casual restaurant sector. Consumers visit the fast-casual restaurants not only for feeding but also to derive some enjoyment from the experience of eating itself. This may require the use of a more entertaining and delighting atmosphere, such as interior and exterior restaurant design, music, and lighting, variety of refreshments, professional appearance and behaviors of employees.

On the other hand, the effect of utilitarian value on satisfaction and behavioral intentions is greater for fast-food restaurant sector than fast-casual restaurant sector. But this difference is not statistically significant. This finding shows that in the fast-food restaurant sector, utilitarian and hedonic aspects of customer value are both important predictors of satisfaction and behavioral intentions. Consumers visit fast-food restaurants mainly to obtain a needed refreshment or service and they make their visiting in an efficient and goal-oriented manner such as saving time, etc. Therefore, fast-food restaurateurs should focus on facilitating efficient eating experiences such as convenience, quick serving, and reasonable price. Furthermore, they should consider offering enjoyable and pleasant restaurant environment to customers.

For future researches, it is proposed that different variables such as personal values, consumer characteristics, perceived risk and service quality that could be related to hedonic and utilitarian values will be inserted into the study model for extending the study area. Additionally, it is suggested that the relationships between hedonic and utilitarian values and other dimensions of behavioral intentions such as switching, paying more and complaining should be investigated for increasing the contribution of the study to the literature. In these relationships, the mediation effect of satisfaction will also be investigated for analyzing the direct and indirect effects of variables extensively.

There are some limitations of the study findings in generalizability. The most important limitation of the study is that it was only carried out on young consumers. Therefore, future studies should include a broad range of customers 
from different age groups to analyze the relationships. Additionally, the data of this research was gathered by using the convenience sampling method. This method reduces the degree of the generalization, despite frequent use for data collection. Thus, further studies carrying out by random sampling methods will contribute to the generalization of the outcomes and development of the research. Also, this study focuses on the service value within the scope of hedonic and utilitarian aspects. Hence, the implementation of the study was carried out on the fast-food and fast-casual restaurant segments. More researches are needed within other service or restaurant sectors for enhancing the generalization and making comparisons.

\section{References}

Anderson, J. C., \& Gerbing, D. W. (1988). Structural equation modelling in practice: A review and recommended two-step approach. Psychological Bulletin. 103(3), 411-423. http://dx.doi.org/10.1037/0033-2909.103.3.411

Babin, B. J., Darden, W. R., \& Griffin, M. (1994). Work and/or fun: Measuring hedonic and utilitarian shopping value. Journal of Consumer Research, 20(4), 644-656. http://dx.doi.org/0093-5301/94/2004-0011

Babin, B. J., Lee, Y. K., Kim, E. J., \& Griffin, M. (2005). Modeling consumer satisfaction and word-of-mouth: Restaurant patronage in Korea. Journal of Services Marketing, 19(3), 133139. http://dx.doi.org/10.1108/08876040510596803

Batra, R., \& Ahtola, O. T. (1990). Measuring the hedonic and utilitarian sources of consumer attitudes. Marketing Letters, 2(2), 159-170. http://dx.doi.org/10.1007/BF00436035

Byrne, B. M. (2010). Structural Equation Modeling with AMOS: Basic Concepts, Applications and Programming (2nd ed.). New York, NY: Routledge Taylor and Francis Group.

Carpenter, J. M. (2008). Consumer shopping value, satisfaction and loyalty in discount retailing. Journal of Retailing and Consumer Services, 15(5), 358-363. http://dx.doi.org/10.1016/j.jretconser.2007.08.003

Chang, H. H., \& Fang, W. (2012). The effects of shopping value on retail outcomes: A comparison between department stores and hypermarkets. The Service Industries Journal, 32(14), 2249-2263. http://dx.doi.org/10.1080/02642069.2011.582494

Chiu, C. M., Wang, E. T. G., Fang, Y. H. \& Huang, H. Y. (2014). Understanding customers' repeat purchase intentions in $\mathrm{B} 2 \mathrm{C}$ e-commerce: the roles of utilitarian value, hedonic value and perceived risk. Information Systems Journal, 24(1), 85-114. http://dx.doi.org/10.1111/j.1365-2575.2012.00407.x

Churchill, G. A., \& Surprenant, C. (1982). An investigation into the determinants of customer satisfaction. Journal of Marketing Research, 19(4), 491-504. http://dx.doi.org/10.2307/3151722

Cottet, P., Lichtle, M. C., \& Plichon, V. (2006). The role of value in services: A study in a retail environment. Journal of Consumer Marketing, 23(4), 219-227. http://dx.doi.org/10.1108/07363760610674347 
Eroglu, S. A., Machleit, K., \& Barr, T. F. (2005). Perceived retail crowding and shopping satisfaction: The role of shopping values. Journal of Business Research, 58(8), 1146-1153. http://dx.doi.org/10.1207/s15327663jcp0901_3

Fornell, C. (1992). A national customer satisfaction barometer: The Swedish experience. Journal of Marketing, 56(1), 6-21. http://dx.doi.org/10.2307/1252129

Garbarino, E., \& Johnson, M. S. (1999). The different roles of satisfaction, trust, and commitment in customer relationships. Journal of Marketing, 63(2), 70-87. http://dx.doi.org/10.2307/1251946

Ha, J., \& Jang, S. (2010). Perceived values, satisfaction, and behavioral intentions: The role of familiarity in Korean restaurants. International Journal of Hospitality Management, 29(1), 2 13. http://dx.doi.org/10.1016/j.ijhm.2009.03.009

Hanzaee, K. H., \& Khonsari, Y. (2011). A review of the role of hedonic and utilitarian values on customer's satisfaction and behavioral intentions. Interdisciplinary Journal of Research in Business, 1(5), 34-45.

Hirschman, E. C., \& Holbrook, M. B. (1982). Hedonic consumption: Emerging concepts, methods and propositions. Journal of Marketing, 46(3), 92-101. http://dx.doi.org/10.2307/1251707

Irani, N., \& Hanzaee, K. H. (2011). The effects of variety-seeking buying tendency and price sensitivity on utilitarian and hedonic value in apparel shopping satisfaction. International Journal of Marketing Studies, 3(3), 89-103. http://dx.doi.org/10.5539/ijms.v3n3p89

Jones, M. A., Reynolds, K. E., \& Arnold, M. J. (2006). Hedonic and utilitarian shopping value: Investigating differential effects on retail outcomes. Journal of Business Research, 59(9), 974981. http://dx.doi.org/10.1016/j.jbusres.2006.03.006

Josiam, B. M., \& Henry, W. (2014). Eatertainment: Utilitarian and hedonic motivations for patronizing fun experience restaurants. Procedia - Social and Behavioral Sciences 144, 187 202. http://dx.doi.org/10.1016/j.sbspro.2014.07.287

Kazakeviciute, A., \& Banyte, J. (2012). The relationship of consumers perceived hedonic value and behavior. Engineering Economics, 23(5), 532-540. http://dx.doi.org/10.5755/j01.ee.23.5.1975

Kim, J. W., Kim E. J., Kim, S. M., \& Hong, H. G. (2011). Effects of fit with CSR activities and consumption value on corporate image and repurchase intention. International Journal of Business Strategy, 11(1), 35-46.

Kline, R. B. (2011). Principles and Practice of Structural Equation Modelling (3rd ed.). New York, NY: The Guilford Press.

McDougall, G. H. G., \& Levesque, T. (2000). Customer satisfaction with services: Putting perceived value into the equation. Journal of Services Marketing, 14(5), 392-410. http://dx.doi.org/10.1108/08876040010340937

Nejati, M., \& Moghaddam, P. P. (2012). Gender differences in hedonic values, utilitarian values and behavioural intentions of young consumers: Insights from Iran. Young Consumers, 13(4), 337-344. http://dx.doi.org/10.1108/17473611211282581 
Nejati, M., \& Moghaddam, P. P. (2013). The effect of hedonic and utilitarian values on satisfaction and behavioural intentions for dining in fast-casual restaurants in Iran. British Food Journal. 115(11), 1583-1596. http://dx.doi.org/10.1108/BFJ-10-2011-0257

Nunnally, J. C., \& Bernstein, I. H. (1994). Psychometric Theory (3rd ed.). New York, NY: McGraw Hill, Inc.

Oliver, R. L. (1980). A cognitive model of the antecedents and consequences of satisfaction decisions. Journal of Marketing Research, 17(4), 460-469. http://dx.doi.org/10.2307/3150499

Oliver, R. L. (1981). Measurement and evaluation of satisfaction processes in retail settings. Journal of Retailing, 57(3), 25-48.

Oliver, R. L. (2010). Satisfaction: A Behavioral Perspective on the Consumer (2nd ed.). New York, NY: M. E. Sharpe, Inc.

Oliver, R. L., Rust, R. T., \& Varki, S. (1997). Customer delight: Foundations, findings, and managerial insight. Journal of Retailing, 73(3), 311-336. http://dx.doi.org/10.1016/S00224359(97)90021-X

Park, C. (2004). Efficient or enjoyable? Consumer values of eating-out and fast food restaurant consumption in Korea. Hospitality Management, 23(1), 87-94. http://dx.doi.org/10.1016/j.ijhm.2003.08.001

Ryu, K., \& Han, H. (2010). Influence of the quality of food, service, and physical environment on customer satisfaction and behavioral intention in quick-casual restaurants: moderating role of perceived price. Journal of Hospitality \& Tourism Research, 34(3), 310-329. http://dx.doi.org/10.1177/1096348009350624

Ryu, K., Han, H., \& Jang, S. (2010). Relationships among hedonic and utilitarian values, satisfaction and behavioral intentions in the fast-casual restaurant industry. International Journal of Contemporary Hospitality Management, 22(3), 416-432. http://dx.doi.org/10.1108/09596111011035981

Ryu, K., Han, H., \& Kim, T. H. (2008). The relationships among overall quick-casual restaurant image, perceived value, customer satisfaction, and behavioral intentions. International $\begin{array}{llll}\text { Journal of Hospitality } & \text { Management, 27(3), 459-469. }\end{array}$ http://dx.doi.org/10.1016/j.ijhm.2007.11.001

Sarkar, A. (2011). Impact of utilitarian and hedonic shopping values on individual's perceived benefits and risks in online shopping. International Management Review, 7(1), 58-65.

Sekaran, U. (2003). Research Methods for Business: A Skill Building Approach (4th ed.). New York, NY: John Wiley \& Sons, Inc.

Terblanche, N. S., \& Boshoff, C. (2010). Quality, value, satisfaction and loyalty amongst race groups: A study of customers in the South African fast food industry. South African Journal of Business Management, 41(1), 1-9.

Tillotson, J. E. (2003). Fast-casual dining our next eating passion?. Nutrition Today, 38(3), 9194. 
To, P. L., Liao, C., \& Lin, T. H. (2007). Shopping motivations on internet: A study based on utilitarian and hedonic value. Technovation, 27(12), 774-787. http://dx.doi.org/10.1016/j.technovation.2007.01.001

Voss, K. E., Spangenberg, E. R., \& Grohmann, B. (2003). Measuring the hedonic and utilitarian dimensions of consumer attitude. Journal of Marketing Research, 40(3), 310-320. http://dx.doi.org/10.1509/jmkr.40.3.310.19238

Westbrook, R. A. (1987). Product/consumption-based affective responses and postpurchase processes. Journal of Marketing Research, 24(3), 258-270. http://dx.doi.org/10.2307/3151636

Zeithaml, V. A., Berry, L.L., \& Parasuraman, A. (1996). The behavioral consequences of service quality. Journal of Marketing, 60(2), 31-46. http://dx.doi.org/10.2307/1251929 